\title{
Seasonal Movements of Chinook Salmon in Lake Michigan Based on Tag Recoveries from Recreational Fisheries and Catch Rates in Gill-Net Assessments
}

\author{
SARA A. Adlerstein* \\ School of Natural Resources and Environment, University of Michigan, \\ 3010 Dana Building, Ann Arbor, Michigan 48109-1115, USA \\ EDWARD S. RUTHERFORD \\ Institute for Fisheries Research, School of Natural Resources and Environment, \\ University of Michigan, Museum Annex Building, Ann Arbor, Michigan 48109-1084, USA \\ Randall M. Claramunt, David F. Clapp, and John A. Cleevenger \\ Michigan Department of Natural Resources, \\ Charlevoix Fisheries Research Station, Charlevoix, Michigan 49720, USA
}

\begin{abstract}
There are no specific studies of the movements of introduced Chinook salmon Oncorhynchus tshawytscha in Lake Michigan, despite the need for such information for population assessments and stocking allocations. We investigated the seasonal distribution of hatchery-reared Chinook salmon between May and September based on fishery-dependent (recoveries from recreational fisheries of fish marked with coded wire tags [CWTs]) and fishery-independent sources (catches in assessment gill-net surveys). We modeled recoveries by fishing trips in Michigan waters of Lake Michigan to estimate spatially and temporally explicit abundance indices using generalized linear models (GLMs) and accounted for the efficiency among recovery sources (charter boat captain reports, creel clerk interviews, and headhunter collections of CWT samples from charter boat and non-charter boat catches). Recovery levels varied among areas, months, years, and recovery sources, and distribution among areas also varied by month. We used CWT data with lakewide geographical coverage and evaluated the distributions of the absolute numbers of coded-wire-tagged fish recovered in Michigan and Wisconsin waters of Lake Michigan from all possible recovery sources. From both analyses we found that the distribution of Chinook salmon varied seasonally, with displacements from southern areas toward the north from May through summer, from inshore to offshore areas toward the west during summer, and movement back east in the fall. For the analysis of Chinook salmon catch rates in gill-net assessments, we used GLMs to compare levels among months, statistical districts, years, nearshore and offshore areas, and different depths. The temporal and spatial trends were similar to those from the CWT analyses, and the distribution shifted toward deeper waters in July and August. Movement patterns coincided with favorable temperature and prey distribution and were consistent with those exhibited by the Pacific Ocean Chinook salmon population from which the Lake Michigan population originated. Seasonal changes in Chinook salmon distribution influence recreational fisheries, and stocking strategies should consider the influences of movement patterns on fishing opportunities in Lake Michigan.
\end{abstract}

Chinook salmon Oncorhynchus tshawytscha were first stocked into Lake Michigan during 1967 to generate recreational fisheries and control undesirable abundances of alewives Alosa pseudoharengus that had invaded the lake during the 1940s and reached nuisance levels during the 1960s (Tody and Tanner 1966). Both objectives were realized as salmon stocking increased from the 1960 s to the 1980s. The sport fishery contributed an estimated US $\$ 2$ billion to the economy of the Lake Michigan region (Keller et al.

\footnotetext{
* Corresponding author: adlerste@umich.edu
}

Received May 30, 2007; accepted November 20, 2007 Published online April 17, 2008
1990), and alewife populations were "controlled." In the late 1980s, an outbreak of bacterial kidney disease caused massive mortality of Chinook salmon along the southeastern shoreline of Lake Michigan (Nelson and Hnath 1990; Holey et al. 1998). Because of growing concerns about exceeding the lake's carrying capacity for predators (Kitchell and Crowder 1986), lakewide stocking levels were reduced and by 1993 the harvest had severely dropped despite adjusting stocking levels (Bence and Smith 1999). Currently, the species plays a key role in the lake's ecosystems as a top predator suppressing undesirable species, and in the regional economy through support of profitable sport fisheries.

In the late 1980s, management agencies initiated a mass-marking program in Lakes Michigan and Huron 
TABLE 1.- Total number of recoverable Chinook salmon marked with coded wire tags (adjusted by tag retention; Michigan Department of National Resources, unpublished data) by statistical district in Michigan waters of Lake Michigan (see Figure 1). No fish were marked after 1994.

\begin{tabular}{|c|c|c|c|c|c|c|}
\hline \multirow[b]{2}{*}{ Year } & \multicolumn{6}{|c|}{ Statistical district } \\
\hline & MM-3 & MM-4 & MM-6 & MM-7 & MM-8 & Total \\
\hline 1990 & 98,393 & & 295,361 & 187,724 & & 581,478 \\
\hline 1991 & 105,647 & 95,487 & 288,107 & 295,436 & 99,555 & 884,592 \\
\hline 1992 & 100,302 & 97,458 & 288,583 & 279,027 & 97,266 & 862,636 \\
\hline 1993 & 86,102 & 81,724 & 282,625 & 283,871 & 82,392 & 816,714 \\
\hline 1994 & 84,577 & 90,756 & 256,390 & 274,030 & 98,281 & 804,034 \\
\hline Total & 475,021 & 365,425 & $1,411,066$ & $1,320,088$ & 377,494 & $3,953,278$ \\
\hline
\end{tabular}

to estimate Chinook salmon natural reproduction and poststocking survival and to track fish movements. As part of the marking program, about 4,000,000 smolts implanted with coded wire tags (CWTs) were stocked in Michigan waters of Lake Michigan from 1990 to 1994 (Table 1; Figure 1), and about 30,000-50,000 were released annually in Wisconsin waters. Most tagged fish were released in the east-central region of Lake Michigan (Figure 1) and the majority of recoveries from these stocking events were made by 1999.

While assessment of Chinook salmon stocks in the Great Lakes requires an understanding of population distributions, few studies have elucidated this species' seasonal movement patterns. Based on limited movement information, Chinook salmon stocks in Lakes Michigan and Huron are currently treated as a single management unit or stock (Johnson et al. 2005). For Lake Michigan, justification for the single-stock approach lay in movement information derived from studies of Chinook salmon diet, catch rates in recreational fisheries, and tag recoveries from marked fish. Elliott (1993) found that Chinook salmon diets reflected the abundance of their alewife prey, which leave nearshore areas in the spring and return to these waters in the fall. Keller et al. (1990) evaluated the spatial distribution of the recreational harvest in Lake Michigan and described the catch rates as being very variable across the lake throughout the years. The report implied that there was one single Chinook salmon stock with patterns in distribution that can be interpreted as the result of high mobility. Moreover, Benjamin and Bence (2003) described spatial trends in Chinook salmon catch rates in the noncharter recreational fishery of Lake Michigan from 1986 to 1996 that corresponded with areas of high concentrations of alewife prey, which also suggest that Chinook salmon can undergo seasonal movements. Johnson et al. (2005) reported substantial migration by Chinook salmon between Lakes Michigan and Huron based on absolute numbers of CWT recoveries. In Lake Huron,
Adlerstein et al. (2007a), based on CWT recovery rates, found that Chinook salmon released along the west coast of the lake moved near shore during early spring and north during summer, returned mostly to areas near stocking locations in summer and fall, and later moved east to deep overwinter areas.

We investigated the seasonal movements of hatchery-reared Chinook salmon in Lake Michigan through analysis of their spatial and temporal distributions based on two independent sources of information: (1) recoveries of Chinook salmon marked with CWTs, released in Lake Michigan, and recovered in Lake Michigan from recreational fisheries, assessment surveys, and weirs, and (2) Chinook salmon catch rates in routine gill-net assessment surveys conducted to evaluate trends in the relative abundance of salmonine populations. Understanding seasonal movement patterns is useful for evaluating trends in the recreational fishery and assisting managers with improving stocking strategies.

\section{Methods}

\section{Analysis of Chinook Salmon CWT Recoveries}

General approach.-The analysis of tag recovery data requires consideration of the effort spent catching fish (Hilborn 1990; Schmalz et al. 2002) and the efficiency in recovering tags. In Lake Michigan, CWT recovery programs were carried out in Michigan, Indiana, Illinois, and Wisconsin waters, although the protocols differed among state programs. Tags were recovered from recreational fisheries, assessment surveys, and operations at weirs; however, the efficiency varied among these recovery sources. Data from these sources cannot be combined for a study of population distribution because effort is in different units and the operations were carried out at different spatial and temporal resolution. In Lake Huron, Adlerstein et al. (2007a, 2007b) demonstrated the feasibility of using CWT data to investigate movements of Chinook salmon and lake trout Salvelinus namaycush from CWT recovery rates in recreational 


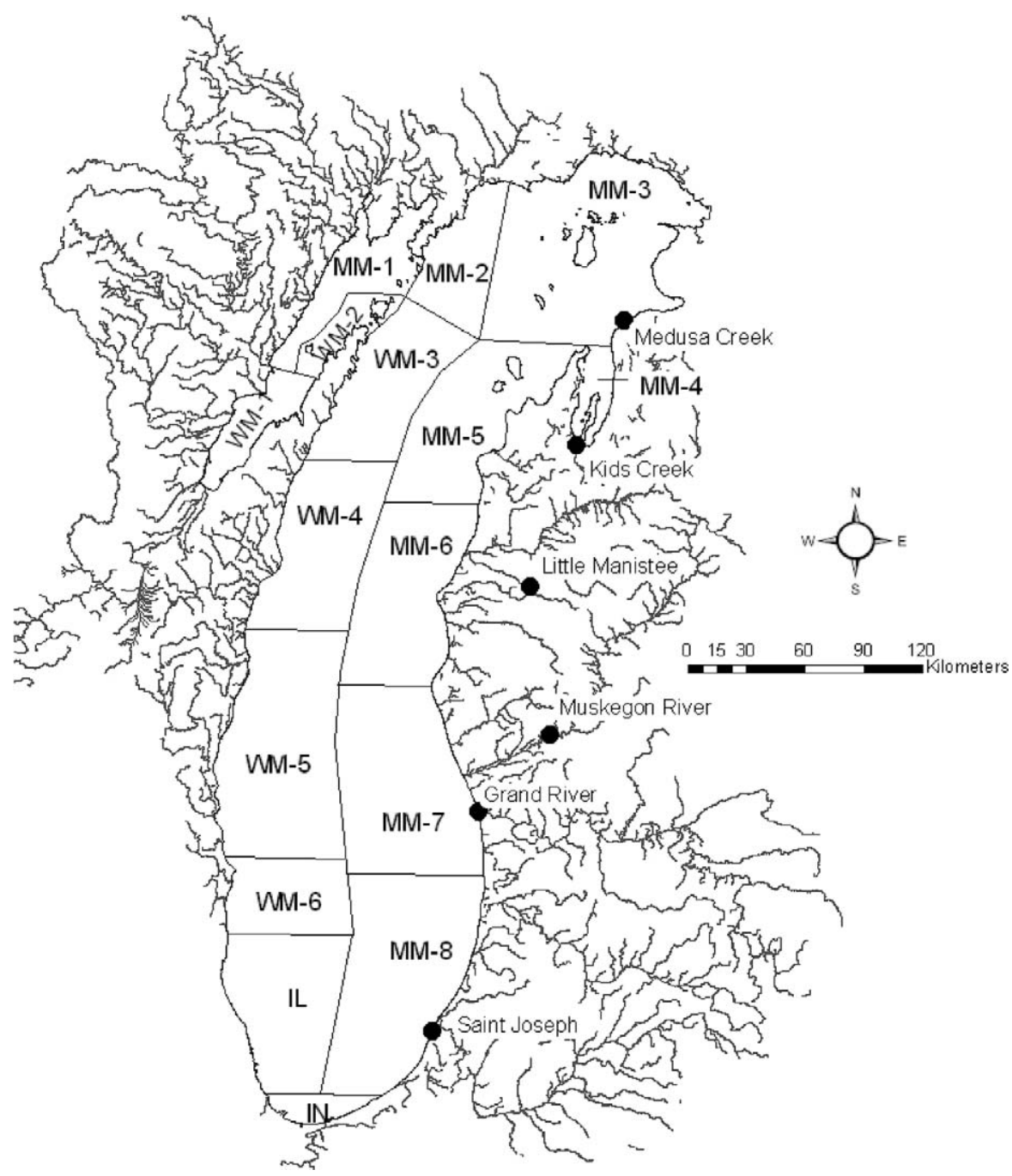

FIGURE 1.- Statistical districts of Lake Michigan. The circles indicate the release sites of coded-wire-tagged Chinook salmon.

fisheries. In this study, our general approach to analyzing CWT data is similar to that described in Adlerstein et al. (2007a, 2007b); we used CWT recovery numbers and recovery effort within a regression approach to develop spatially and temporally explicit abundance indices.

We based the current analysis on recoveries of codedwire-tagged fish from recreational fisheries in Michigan waters of Lake Michigan (Figure 1) reported to or collected by the Michigan Department of Natural Resources (MDNR). We analyzed movement from fish released along the east coast of Lake Michigan by selecting CWT recoveries from fish that were released in Michigan waters. We modeled CWT recoveries by trip using Generalized Linear Models (GLM) (McCul- lagh and Nelder 1989). We inferred seasonal movements under the assumptions that monthly variations in recoveries by trips within years are mainly due to movements where (1) general decreases in catch rates in all study areas in Michigan waters are caused by movements offshore (i.e., away from the eastern coast of Lake Michigan) and (2) changes in the relative levels of recoveries by trips among areas where decreases in some areas co-occurred with increases in others are caused by movements along the east coast. To complement the GLM analysis and expand the spatial distribution of CWT recoveries, we examined displacement using absolute numbers of tagged fish released and recovered in Michigan and Wisconsin waters. 
Data sources.-Coded wire tag data were gathered from the MDNR CWT database, and information on fishery catch and effort was from the MDNR creel, charter boat and headhunter fishery databases. Headhunters are CWT collection specialists employed by the MDNR to monitor the recreational salmonid fishery and inspect anglers' catches for Chinook salmon and other salmonids. Headhunters search exclusively for specimens with missing adipose fins, which indicate the presence of CWT tags, and collect the fish snout or head and record recovery data. In contrast, creel clerks only collect tagged fish occasionally, instead concentrating on counts and interviews to measure recreational fishing effort and harvest.

We used data from only the boat fishery, which excludes fishing from piers, ice shanties, and shore, for which the unit of effort is not a fishing trip. Data from CWT recoveries were obtained from fish tagged and released as smolts. The CWT is an engraved piece of wire, $0.25 \mathrm{~mm}$ in diameter, that is inserted in the snout of the fish before release. Recovered fish have the snout removed for tag extraction and interpretation. The code is then read under a microscope, and the data are entered into the CWT database. Tagging and tag recovery procedures are described in detail at the MDNR Web site (www.michigan.gov/dnr) and summarized in Adlerstein et al. (2007b).

For the regression analysis we evaluated data from 1,987 coded-wire-tagged Chinook salmon (Table 2). Data were from marked fish recovered from the Lake Michigan recreational fisheries, including those reported by charter boat captains, and those sampled by creel clerks and headhunters between May and September in statistical districts MM-4 to MM-8 of Lake Michigan (Figure 1). Although some tagged fish were released in MM-3 (Table 1), the number of recoveries from recreational fisheries in MM-3 was minimal, as were numbers of recoveries in MM-1 and MM-2. Most recoveries were made in the east-central region of Lake Michigan (MM-7) and by charter boat captains (Table 2). Data were from recreational fisheries conducted from 1993, when the headhunter program started, until 1999, when most of the CWTs from fish stocked in 1990-1994 had been recovered. We excluded data from 539 CWT-marked fish recovered from anglers that reported tags voluntarily, for which the number of trips to recover tags was not recorded.

The fishery data (creel and charter boat) in the analysis consisted of catch information by fishing trip, date, fishing location, and site of the interview. We used trip as the measure of fishing effort. To pair CWT recoveries with the trips conducted in the recreational fisheries, we aggregated the CWT and effort data by month, statistical district of recovery, and type of
TABLE 2.-Numbers of Chinook salmon marked with coded wire tags released in Michigan waters of Lake Michigan and recovered between 1993 and 1999 in recreational fisheries. Source abbreviations are as follows: $\mathrm{CBT}=$ reported by charter boat captains, $\mathrm{CCK}=$ derived from creel clerk interviews, $\mathrm{HHB}=$ headhunter sampled from charter boat fisheries, and HHR = headhunter sampled from non-charter boat fisheries.

\begin{tabular}{lrrrrr}
\hline \multirow{2}{*}{$\begin{array}{c}\text { Statistical } \\
\text { district }\end{array}$} & CBT & CCK & HHB & HHR & Total \\
\cline { 2 - 6 } & 4 & 37 & 0 & 0 & 41 \\
MM-4 & 17 & 41 & 9 & 11 & 78 \\
MM-5 & 318 & 119 & 63 & 144 & 644 \\
MM-6 & 512 & 90 & 167 & 144 & 913 \\
MM-7 & 28 & 109 & 68 & 106 & 311 \\
MM-8 & 879 & 396 & 307 & 405 & 1,987 \\
Total & & & & & \\
\hline
\end{tabular}

fishery, and we matched the number of tagged fish with the corresponding effort for each source of recovery.

For the analysis of the absolute number of CWT recoveries, we used data from 7,659 coded-wire-tagged Chinook salmon released and recovered in Michigan and Wisconsin waters from all sources of recovery recorded in the MDNR CWT database (Table 3). These sources included those indicated previously as well as additional sources not used in the regression analysis because they could not be related to effort data (e.g., weirs, assessments, and volunteer returns from recreational fisheries). Recoveries from Wisconsin waters were from volunteers, weir returns, and unidentified sources.

Estimation of effort.-To estimate the fishing effort for CWT recoveries, we selected fishing trips that had the potential to catch Chinook salmon. The recreational fisheries in Lake Michigan target multiple species and the chances of catching a particular species varies with the species targeted. Thus, including all fishing trips in the fisheries could bias the analysis if the proportion of fishing trips with probability of catching Chinook salmon varies in time and space. Using the species catch composition, we determined that Chinook salmon were practically absent in catches from the Michigan recreational fisheries when yellow perch Perca flavescens were present, both in chartered and nonchartered trips. Thus, we excluded trips with yellow perch. Based on this definition, fishing trips for the analysis that had the potential to catch Chinook salmon, ranged from 12,000 to 19,000 trips per year. One-third of the selected trips were conducted annually in statistical district MM-6, less than 5\% in MM-4, and about $20 \%$ in each of the other areas.

Statistical analysis.-For the GLM analysis of recovery data we used the following model: 
TABLE 3.- Number of coded wire tag recoveries from Chinook salmon released and recovered in Michigan and Wisconsin waters of Lake Michigan from all recovery sources. Releases were between 1990 and 1994 and recoveries between 1993 and 1999.

\begin{tabular}{|c|c|c|c|c|c|c|c|c|}
\hline \multirow{3}{*}{$\begin{array}{l}\text { Recovery } \\
\text { site }\end{array}$} & \multicolumn{7}{|c|}{ Release site } & \multirow[b]{3}{*}{ Total } \\
\hline & \multicolumn{5}{|c|}{ Michigan } & \multicolumn{2}{|c|}{ Wisconsin } & \\
\hline & MM-3 & MM-4 & MM-6 & MM-7 & MM-8 & WM-3 & WM-4 & \\
\hline \multicolumn{9}{|l|}{ Michigan } \\
\hline MM-1 & 9 & 8 & 3 & 4 & 4 & 0 & 0 & 28 \\
\hline MM-2 & 10 & 2 & 0 & 0 & 0 & 23 & 2 & 37 \\
\hline MM-3 & 697 & 33 & 5 & 6 & 2 & 4 & 1 & 748 \\
\hline MM-4 & 173 & 453 & 13 & 8 & 3 & 4 & 4 & 658 \\
\hline MM-5 & 612 & 145 & 65 & 24 & 8 & 52 & 9 & 915 \\
\hline MM-6 & 267 & 131 & 2,417 & 267 & 73 & 164 & 21 & 3,340 \\
\hline MM-7 & 154 & 86 & 199 & 469 & 75 & 106 & 19 & 1,108 \\
\hline MM-8 & 66 & 23 & 86 & 87 & 124 & 69 & 14 & 469 \\
\hline \multicolumn{9}{|l|}{ Wisconsin } \\
\hline WM-1 & 17 & 23 & 13 & 26 & 8 & & & 87 \\
\hline WM-2 & 8 & 6 & 4 & 10 & 6 & & & 34 \\
\hline WM-3 & 33 & 15 & 28 & 25 & 11 & & & 112 \\
\hline WM-5 & 22 & 14 & 13 & 40 & 17 & & & 106 \\
\hline WM-6 & 2 & 3 & 3 & 7 & 2 & & & 17 \\
\hline Total & 2,070 & 942 & 2,849 & 973 & 333 & 422 & 70 & 7,659 \\
\hline
\end{tabular}

$$
g\left(\mu_{\mathrm{ymdg}}\right)=\alpha+\delta_{y}+\Phi_{m}+\lambda_{d}+\tau_{g},
$$

where $g\left(\mu_{\text {ymdg }}\right)$ is a link function, $\mu$ is the expected number of coded-wire-tagged Chinook salmon recovered by the corresponding number of trips, $\delta$ is the year, $\Phi$ is the month, $\lambda$ the statistical district, and $\tau$ the source of tag recovery. We included the recovery source as a variable to account for differences in efficiency among recovery sources. Coded wire tag recoveries from the noncharter fishery were made by clerks during creel interviews and by headhunters. Recoveries from the charter fishery were reported by charter boat captains and also sampled by headhunters. We introduced the recovery source as an explanatory factor variable with four corresponding levels. The models incorporated a binomial distribution to describe the probability of obtaining a given number of tags with the associated number of trips. Each trip was treated as a Bernoulli trial with the expected catch of tagged fish constrained between 1 and 0 . Although multiple CWT recoveries by fishing trip are possible, the expected number was always very small because not all fish were coded-wire-tagged and fishing regulations established daily limits of five salmonid individuals, no more than three of which could be Chinook salmon (Rutherford 1997). We evaluated performance of logit- and probit-link functions, and selected the logit function, which is the canonical link for the binomial family. First-order interactions were investigated. Higher-order interactions were not tested as they were of minor interest and data were limited. We performed analysis of deviance to test the significance of explanatory variables. We ran model diagnostics, including checking model residuals and estimating the dispersion parameter of the binomial models, to check the validity of the model assumptions.

\section{Analysis of Catch per Effort from Assessment Gill-Net Surveys}

We evaluated Chinook salmon catch rate data from an ongoing fishery-independent gill-net survey conducted by MDNR since 1990. We used data from surveys conducted in May through August 1994-1997 from sites located in Lake Michigan statistical districts MM-3, MM-5, MM-6, MM-7, and MM-8 (Figure 1). The graded-mesh gill nets consisted of two units, each $244 \mathrm{~m}$ in length and $9 \mathrm{~m}$ in height and having eight panels $30.5 \mathrm{~m}$ in length separated by a minimum of 2 $\mathrm{m}$. The stretched-mesh sizes of the nets ranged from 76.2 to $177.8 \mathrm{~mm}$ in $12.7 \mathrm{~mm}$ increments (Schneeberger et al. 2001). Four units were set at each station. Gill nets were constructed mostly of monofilament nylon, although from 1994 to 1996 multifilament nylon panels were used in some nets. Catches per effort (CPEs) obtained with the multifilament nets were standardized by subtracting 0.034 and multiplying by 1.349 (Henderson and Nepszy 1992). Data from each statistical district were from two strata; nearshore sets were conducted at distances from 1 to $3 \mathrm{~km}$ from shore where depth varied from 15 to $45 \mathrm{~m}$, and offshore sets were conducted at distances from 10 to $13 \mathrm{~km}$ from shore where depths varied from 46 to $92 \mathrm{~m}$. Data from nearshore stations were from nets set at the surface (covering the water column from 0 to $9 \mathrm{~m}$ ) and data 
TABLE 4.-Analysis of deviance table for main effects in the generalized linear model of coded wire tag recoveries by trip. All predictors were incorporated as factors. The model incorporates binomial variance and logit-link functions.

\begin{tabular}{lrrccc}
\hline \multicolumn{1}{c}{ Term } & df & Deviance & Residual df & $\begin{array}{l}\text { Residual } \\
\text { deviance }\end{array}$ & Chi-square $P$ \\
\hline Null model & 532 & $4,050.7$ & & & \\
Recovery source & 3 & 669.5 & 529 & 3,381 & $<0.00001$ \\
Year & 6 & 875.8 & 523 & 2,505 & $<0.00001$ \\
Statistical district & 4 & 674.6 & 519 & 1,831 & $<0.00001$ \\
Month & 4 & 137.1 & 515 & 1,694 & $<0.00001$ \\
Full model & 515 & $1,693.7$ & & & \\
\hline
\end{tabular}

from offshore stations were from nets set both at the surface and also suspended from 10 to $30 \mathrm{~m}$ in the water column. Both surface and suspended nets were set at multiple sites within each statistical district. The target time for a net set was approximately $4 \mathrm{~h}$ after sunset. For each set, catch was identified to species, enumerated, and weighed. The catch was recorded separately for surface and suspended panels. Temperature was recorded for all sets.

We used data from 172 gill-net sets in our analyses. A total of 2,944 Chinook salmon were caught during these sets. We used total catch of Chinook salmon regardless of age. Catches per effort were referenced to a standard net length of $305 \mathrm{~m}$ and fishing time of $4 \mathrm{~h}$. We evaluated seasonal distribution of Chinook salmon in several dimensions: east-west, proximity to shore, north-south, and depth. First, to investigate distribution along Michigan districts and with respect to Michigan shores, we used the following model:

$$
g\left(\mu_{\mathrm{ymsd}}\right)=\alpha+\delta_{y}+\Phi_{m}+\lambda_{s}+v_{d}
$$

where $v$ the distance to shore and the other terms are as in equation (1). All variables in the linear predictor were introduced as factors. Distance to shore was introduced as a two-level factor (nearshore and offshore stations). Next, to investigate seasonal distribution of Chinook salmon in the water column, we modeled CPE in offshore gill-net sets. We used a similar model except that $v$ is the depth gill nets were set. All variables in the linear predictor were introduced as factors. The depth gill nets were set was incorporated as a two-level factor (surface and suspended nets). We tested for first-order interactions. Both models incorporated a Gamma distribution as we determined that the CPE variance increased approximately with the square of the CPE mean. We used a logarithmic link to relate the linear predictor to the expected CPE (McCullagh and Nelder 1989).

All tests in the GLM analysis of CWT recoveries and of catch rates in gill-net assessments were performed at the $95 \%$ confidence level. The GLMs were run with routines contained in the S-Plus programming environment (Becker et al. 1988).

\section{Results \\ GLM Analysis of CWT Recoveries by Trip}

An average of 15 coded-wire-tagged Chinook salmon was recovered from the catch for every 1,000 trips in the Lake Michigan recreational fisheries in Michigan waters. The GLM recovery rates varied significantly in time (month and year) and space and also among recovery sources, with largest variation among years (Table 4). The main-effect GLM incorporating statistical district, month, year, and source of recovery explained $60 \%$ of the variability in tag recoveries by trip (Table 4). Recovery levels decreased from May to August and increased in September (Figure 2), suggesting that fish moved away from Michigan districts during spring and summer and back during September. Recovery levels were highest in the lake's central areas, particularly statistical district MM-7 from May to September (Figure 2). Levels decreased sharply after 1996 (Figure 2) as a result of discontinuation of the Lake Michigan CWT Chinook salmon tagging program in 1994. Levels were highest when headhunters reported tags from charter trips, followed by headhunters reporting from noncharter trips and charter boat captains' selfreporting tags, and were lowest when creel clerks reported tags from noncharter trips (Figure 2).

The relative recovery levels among statistical districts varied significantly with month (district $X$ month interaction; $P<0.0001)$. The variation was such that recovery levels in MM-8, the most southern area, and in May were similar to those in MM-7 and MM-6 (Figure 3), and decreased during June through August as levels in MM-6 became relatively higher. By September the distribution among areas was similar to that in May (Figure 3). Based on these patterns, Chinook salmon presumably concentrated along the southeast coast of Lake Michigan in winter and moved toward the central coast region in June and July. The interaction between recovery sources and year also was 

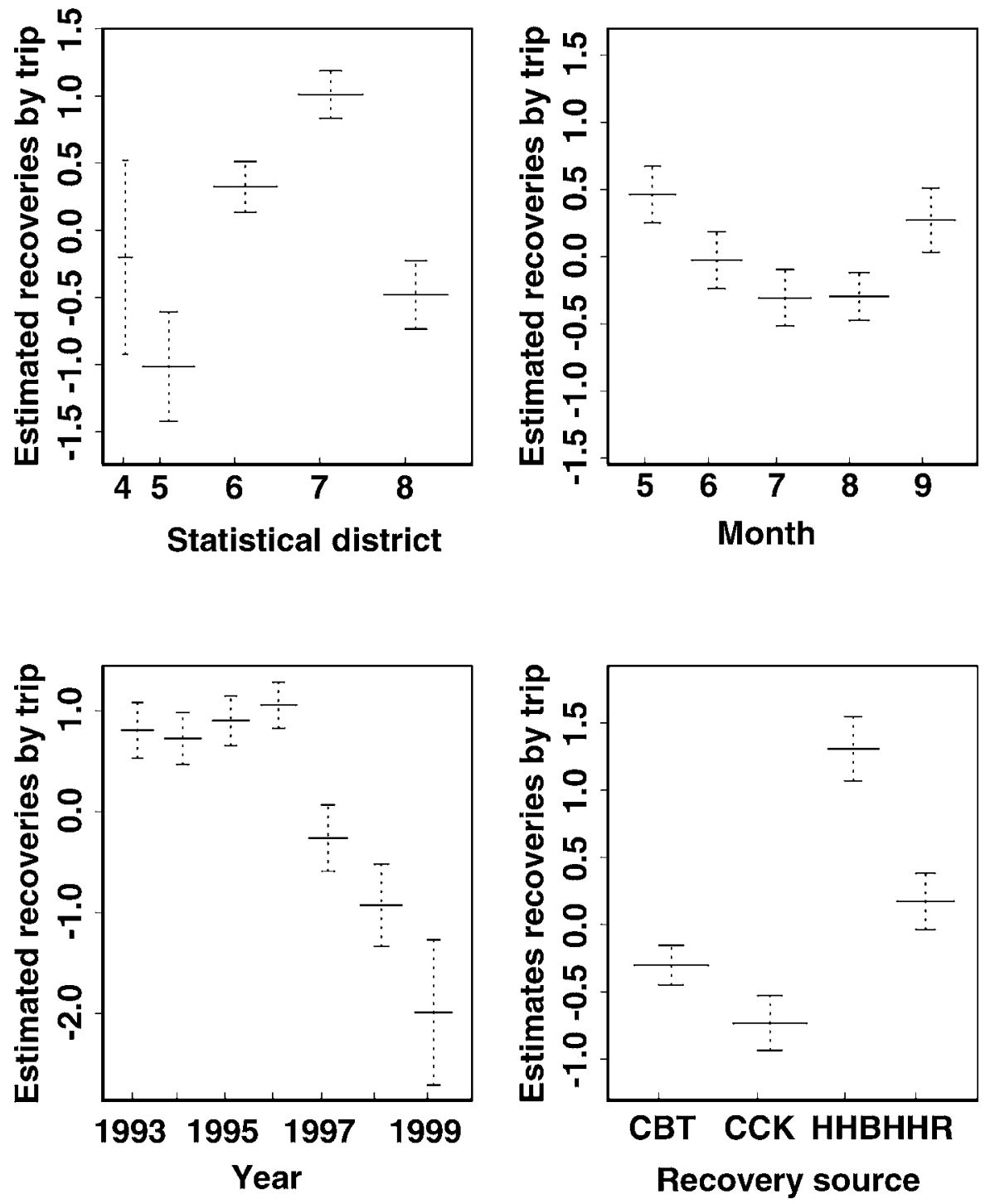

FigURE 2.-Fitted GLM effects for recoveries of Chinook salmon implanted with coded wire tags by trip as a function of statistical district, month, year, and source of recovery. The model incorporates binomial variance and logit-link functions. Statistical districts 4-8 correspond to areas MM-4 to MM-8 in Figure 1. Recovery sources are as follows: CBT = self-reported recoveries of tags from charter boat trips, $\mathrm{CCK}=$ recoveries of tags by creel clerks on non-charter boat trips, $\mathrm{HHB}=$ recoveries of tags by headhunters on charter boat trips, and HHR $=$ recoveries of tags by headhunters on non-charter boat trips. The $y$-axes are standardized so that zero corresponds to the mean number of tag recoveries by trip. The lengths of the line segments representing the mean fitted values are proportional to the numbers of observations available for the model factors. The vertical dotted lines represent $95 \%$ confidence intervals.

significant $(P=0.049)$, and indicated relatively higher reported recoveries by trip from charter boat captains relative to other sources in 1996, when awareness increased of outreach education and reward programs were more successful than in other years (MDNR, unpublished data). Other interactions were not significant $(P>0.10)$.

\section{Analysis of the Absolute Number of CWT Recoveries} to Assess Longitudinal Movements

The absolute numbers of CWT recoveries indicate the movements of Chinook salmon between the east and west coasts of Lake Michigan, giving further support for the patterns found from the GLM analysis. A total of $356 \mathrm{CWTs}$ from fish released in Michigan 

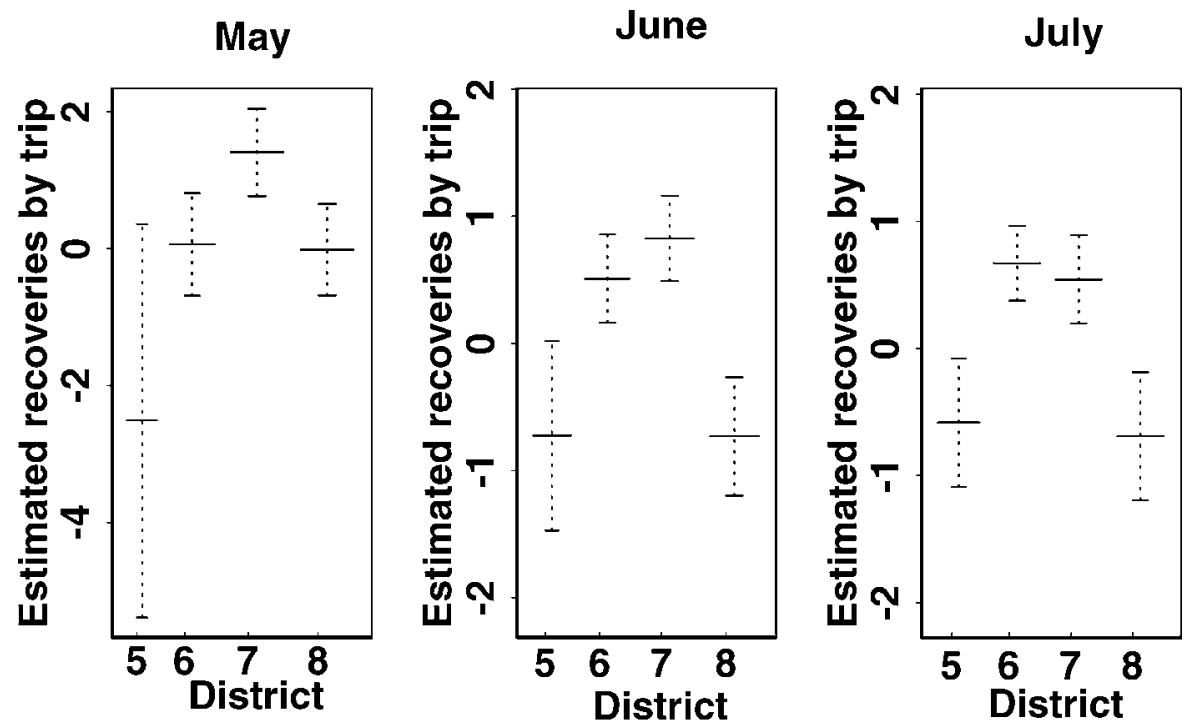

August

September
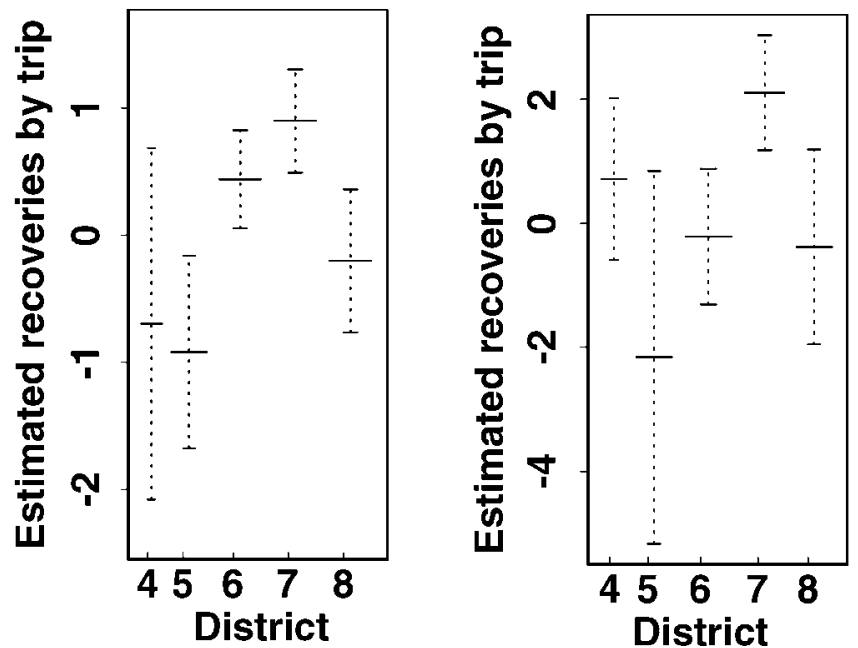

FIGURE 3.-Fitted GLM effects for recoveries of Chinook salmon implanted with coded wire tags by trip from May to September as a function of statistical district. See Figure 2 for additional details.

waters were recovered in Wisconsin in statistical districts WM-1 to WM-6 (Table 3). Also, 492 tagged Chinook salmon released in Wisconsin waters of Lake Michigan were recovered in Michigan waters in statistical areas MM-2 to MM-8 (Table 3). The highest recoveries of Wisconsin-tagged fish in Michigan were in MM-6 and MM-7 during July and August. Most recoveries of Michigan-tagged fish in Wisconsin were in WM-1, WM-3, and WM-5, also during July and August. Although these numbers do not account for fishing and recovery effort, they indicate that regard- less of region of origin (east or west shoreline), fish moved offshore and probably became mixed during July and August as the summer progressed. If our GLM analysis had been implemented without identifying the Michigan origin of the fish, the seasonal movement could have been obscured by the movement of fish released in Wisconsin into Michigan waters.

\section{GLM Analysis of Catch Rates from Gill-Net Surveys}

Catch-per-effort levels in the surveys varied significantly through the season ("month"; Table 5); CPEs 
TABLE 5.-Analysis of deviance table for main effects in the generalized linear model of Chinook salmon catch per effort in gill-net surveys. All predictors were incorporated as factors. The model incorporates Gamma variance and logarithmic-link functions.

\begin{tabular}{lrrcrr}
\hline \multicolumn{1}{c}{ Term } & df & Deviance & Residual df & $\begin{array}{r}\text { Residual } \\
\text { deviance }\end{array}$ & Chi-square $P$ \\
\hline Null model & 172 & 258.3 & & & \\
Year & 3 & 87.9 & 169 & 170.1 & $<0.000001$ \\
Month & 3 & 55.4 & 166 & 114.7 & 0.000005 \\
Statistical district & 4 & 24.5 & 162 & 90.2 & 0.001611 \\
Distance to shore & 1 & 10.3 & 161 & 79.9 & 0.006378 \\
Full model & 161 & 79.9 & & & \\
\hline
\end{tabular}

were high during May and June, decreased in July, and trended up again in August (Figure 4), indicating that fish moved out of and back to Michigan districts. Levels of CPE varied significantly within the range of the survey ("statistical district"; Table 5), higher levels occurring in the central and southern districts MM-6 to MM-8 (Figure 4). Catch per effort also varied with distance to shore (Table 5), overall levels being higher in nearshore waters than offshore (Figure 4). The CPE also varied significantly by year (Table 5 ), from the stable levels apparent from 1994 to 1996 to lower levels in 1997 (Figure 4), which cannot be explained by stocking numbers alone (Johnson et al. 2005). The interaction between district and month was not tested as not all districts were sampled from May to August, but the trend was of a transition from highest rates during May in the central and southern areas (MM-8 to MM-6) to highest rates during August in the most northerly area (MM-3) (Table 6). This indicates northward movement of fish from spring through summer. The interaction between distance to shore and month was significant ( $F$-test: $P=0.024)$, with higher rates in nearshore stations during May, similar levels in June, lower rates in nearshore stations during July, and higher levels in nearshore stations in August (Figure 5). This indicates that, within Michigan districts, fish moved offshore in June and July and inshore in August.

Catch-per-effort GLM levels in offshore stations varied with the location of the net in the water column and were higher in surface waters, although the difference was not significant $(F$-test: $P=0.267)$. However, the interaction with month was significant $(P=0.002)$, and rates were higher in surface nets during May and June and in suspended nets in July and August (Figure 6). This indicates that fish moved to deeper waters as the season progressed.

\section{Discussion}

Our results showing the seasonal, latitudinal, longitudinal, nearshore-offshore, and vertical movements of Chinook salmon released in Michigan waters of Lake Michigan are consistent among analyses performed using different approaches as well as with information from related studies. The results from GLM analysis of CWT data from the recreational fisheries show fluctuations in recoveries indicative of Chinook salmon movements from southern areas toward the north from May through summer, and of movements away from the east coast during July and August and back in the fall. Our evaluation of absolute number of CWT recoveries indicates movement of fish released in Michigan into Wisconsin waters during summer. Furthermore, GLM analysis of catch rates in gill-net surveys shows fluctuations indicative of Chinook salmon movement toward the north starting in spring and away from Michigan waters toward the west in late spring and summer as well as within Michigan waters toward offshore deeper areas. These results cannot be directly compared with those of previous studies on Chinook salmon movements in Lake Michigan, but are in general agreement with previous information (Keller et al. 1990; Elliott 1993; Benjamin and Bence 2003). Results on the analysis of spatial distribution of recreational harvest in Lake Michigan described by Keller et al. (1990) and of Chinook salmon diets by Elliott (1993) indicate that the most important drivers of Chinook salmon distribution are temperature and prey. Both temperature and prey experience seasonality consistent with Chinook salmon movements in spring away from nearshore areas and back in the fall (Brandt et al. 1991). Moreover, reported annual changes in distribution leading to Chinook salmon east-west regional trends in the Lake Michigan noncharter recreational fishery were associated with changes in prey distribution (Benjamin and Bence 2003). These changes in distribution were in response to local drivers and suggest that they can also influence seasonal distributions. Results indicating northward movements during spring into summer have not been described.

The Chinook salmon movements reported in this study can be related to environmental cues that include warming water temperatures, thermocline develop- 

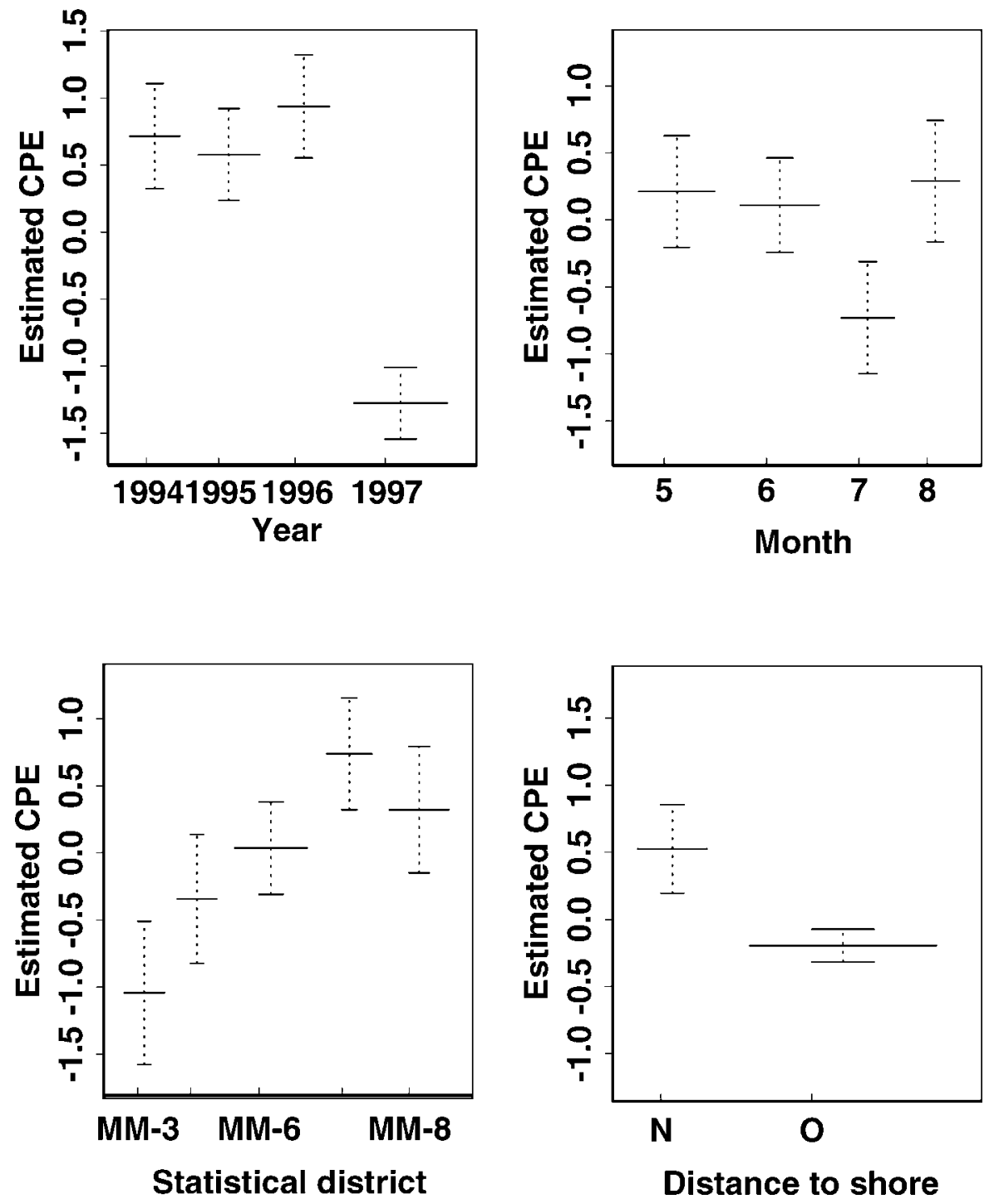

FIGURE 4.-Fitted GLM main effects for Chinook salmon CPE in gill-net sets as a function of year, month, statistical district, and distance to shore $(\mathrm{N}=$ near shore, $\mathrm{O}=$ off shore). The model incorporates Gamma variance and logarithmic-link functions. The $y$-axes are standardized so that zero corresponds to the mean CPE by trip. See Figure 2 for additional details.

ment, and prey distribution and may also be genetically influenced. Fish released in the west coast of Lake Michigan moved toward the east at the same time that fish released in the east moved west. This suggests that the described patterns resulted from movements away from nearshore areas in response to similar biological or environmental cues occurring along both coasts. The distributions of salmonines in the Great Lakes, like those in the Pacific Ocean, are influenced by water temperature (Haynes and Keleher 1986; Haynes et al. 1986; Nettles et al. 1987; Olson et al. 1988; Aultman
TABLE 6. - Monthly Chinook salmon mean catch per effort in gill-net assessment sets between 1994 and 1997 in Michigan waters of Lake Michigan.

\begin{tabular}{llllll}
\hline & \multicolumn{5}{c}{ Statistical district } \\
\cline { 2 - 6 } Month & MM-3 & MM-5 & MM-6 & MM-7 & MM8 \\
\hline May & & & 2.10 & 8.97 & 7.84 \\
Jun & & 3.59 & 7.19 & 9.60 & \multirow{2}{*}{0.79} \\
Jul & 0.31 & 2.31 & 3.49 & 2.10 & \\
Aug & 3.56 & 0.81 & 0.81 & 1.45 & \\
\hline
\end{tabular}




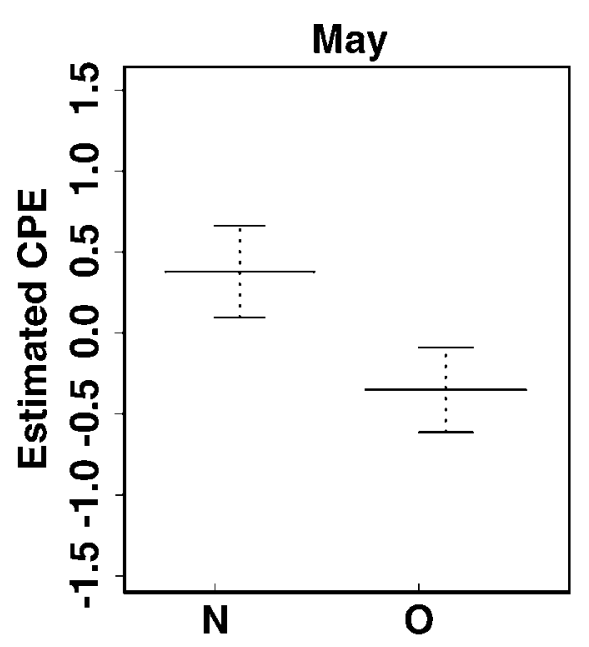

Distance to shore

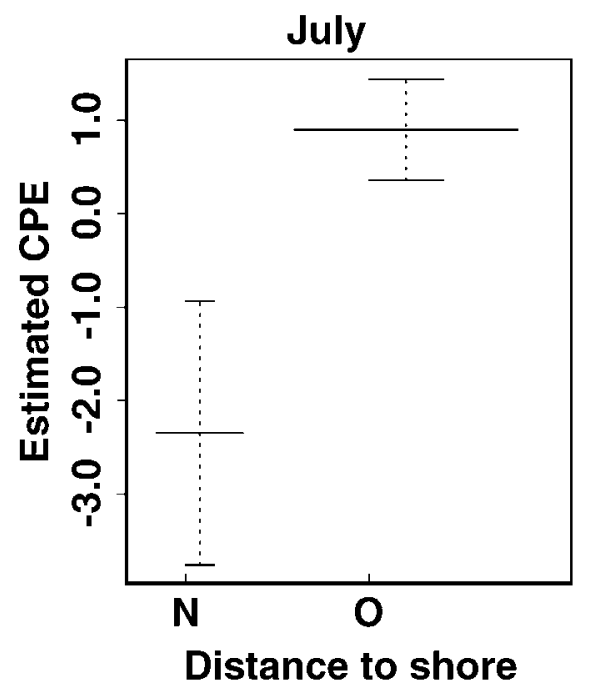

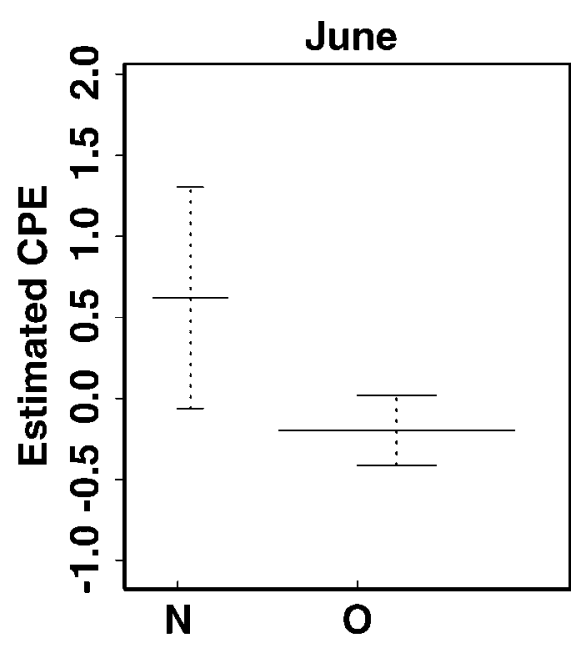

Distance to shore

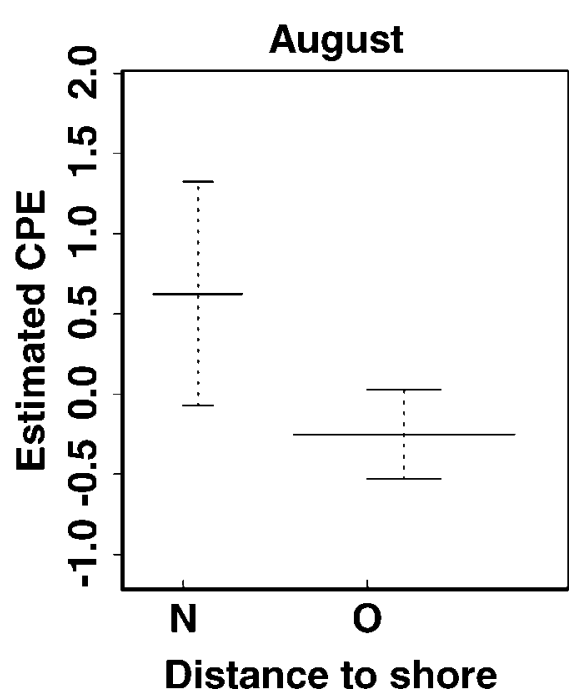

FIGURE 5.-Fitted effects of GLMs by month for Chinook salmon CPE in gill-net sets as a function of distance to shore $((\mathrm{N}=$ near shore, $\mathrm{O}=$ off shore). The model incorporates Gamma variance and logarithmic-link functions. The $y$-axes are standardized so that zero corresponds to the mean CPE by trip. See Figure 2 for additional details.

and Haynes 1993; Höök et al. 2004). Although Chinook salmon are most often found at temperatures around $10-12^{\circ} \mathrm{C}$ (Stewart and Ibarra 1991; Walker et al. 2000; Hinke et al. 2005), during summer individuals can inhabit much warmer waters at temperatures up to $20^{\circ} \mathrm{C}$ (Olson et al. 1988; Wurster et al. 2005). These higher temperatures are within the preference range of alewife prey (Brandt et al. 1991). During spring in the extreme southeastern area of Lake Michigan where higher Chinook salmon densities were found, surface waters of around $8.5-16.5^{\circ} \mathrm{C}$ are approximately $4-6^{\circ} \mathrm{C}$ warmer than in the north and $2-4^{\circ} \mathrm{C}$ warmer than in the west (Brandt et al. 1991). However, during the summer when the thermocline is more pronounced, surface waters can exceed $20^{\circ} \mathrm{C}$. Thus, Chinook salmon probably moved offshore and deeper into the water column in response to these temperature changes. In our study, highest catch rates in the gill-net survey were found when temperatures were around $9^{\circ} \mathrm{C}$ (Figure 7).

In addition to water temperature, environmental cues for Chinook salmon movement in Lake Michigan may 

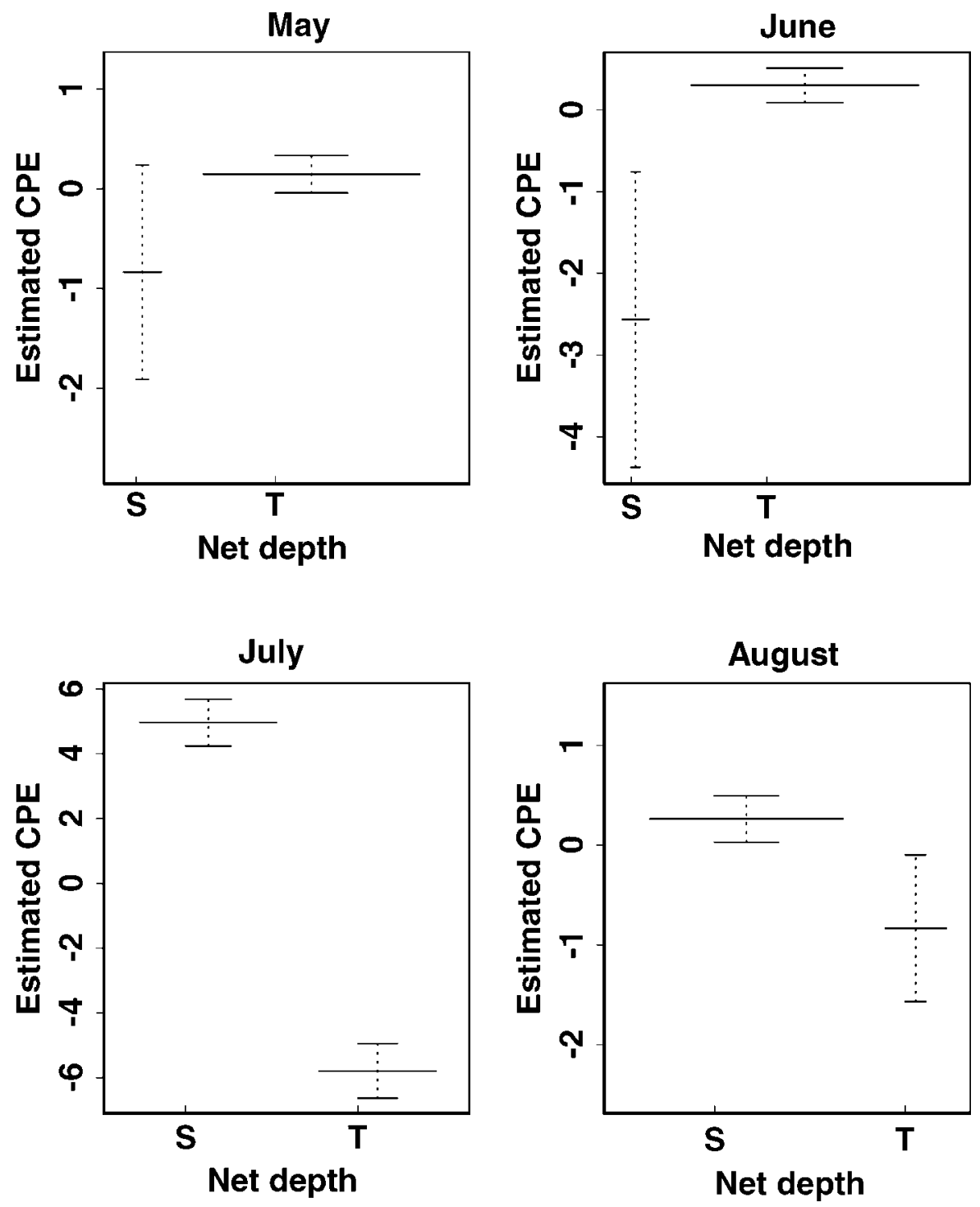

FIGURE 6.-Fitted effects of GLMs by month for Chinook salmon CPE in gill-net sets in offshore stations as a function of distribution in the water column $(\mathrm{S}=$ suspended, $\mathrm{T}=$ surface). The models incorporate Gamma variance and logarithmic-link functions. The $y$-axes are standardized so that zero corresponds to the mean CPE by trip. Note that scale of the $y$-axes varies to show depth effects of different magnitudes among months. See Figure 2 for additional details.

include prey distribution. Alewives and rainbow smelt Osmerus mordax, which undergo seasonal lakewide migrations in the Great Lakes, are the major components of diets of salmonines and especially Chinook salmon in Lake Michigan (Rybicki and Clapp 1996; Madenjian et al. 2002) and Lake Huron (Diana 1990; Dobiesz et al. 2003). Alewives move from deep wintering areas toward shallow waters in spring as water temperatures increase, and to deeper waters in the fall (Brown 1972; Argyle 1982; Brandt et al. 1991).
In our study, seasonal increases in the catch rates of Chinook salmon in the gill-net surveys within a particular year corresponded with increases in the numbers of alewives found in their stomachs (MDNR, unpublished data). Thus, decreasing catch rates of Chinook salmon near shore found in this study could be explained by movements of prey offshore, where studies have reported higher densities of alewives during mid to late summer (Brandt et al. 1991; Warner et al. 2006). The northwards movement trend can not 


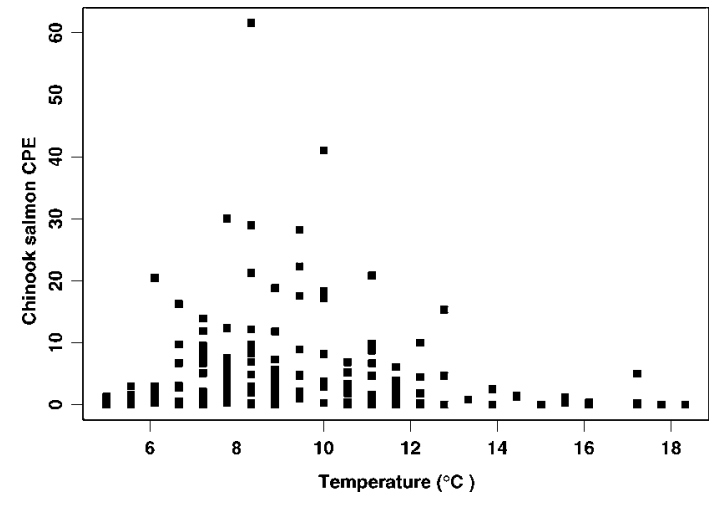

FIGURE 7.-Catch per effort for Chinook salmon in gill-net surveys as a function of temperature.

only be related to environmental cues but is also consistent with the hypothesis of genetic influence on the movement of Chinook salmon. Chinook salmon populations in the northeast Pacific Ocean exhibit movement patterns that have been interpreted as being heritable (Myers et al. 2005). After ocean entry, Chinook salmon from the Green River, Washington, population, the original source of eggs for salmon stocked in Lakes Michigan and Huron, remain in coastal waters and move primarily northwards during spring and summer. The movement patterns in the Lake Huron stock were also similar to those of the populations from the Green River (Adlerstein et al. 2007a).

A general criticism of interpreting monthly changes in CWT recovery rates from recreational fisheries as seasonal changes in distribution is the potential influence of fisher behavior, such as shifts in the target species sought. We interpreted our GLM results showing variation in CWT recoveries during JulyAugust and increases toward the fall as indicative of seasonal movements. Findings of coded-wire-tagged fish tagged in Michigan and recovered in Wisconsin, and results from analysis of catch rates in a fisheryindependent gill-net survey, indicated seasonal changes in Chinook salmon distributions and give credibility to our seasonal movement interpretations.

The GLM results indicating higher chances of recovering tagged Chinook salmon in the charter than the noncharter fishery and when reported by headhunters are consistent with findings in recovery efficiency in Lake Huron recreational fisheries (Adlerstein et al. 2007a). Higher recoveries by trip among charter operations occur because the numbers of anglers per boat and rods per angler (not reported) are higher in the charter fishery, trips tend to be longer, and captains have greater experience in catching fish. Higher recoveries among headhunter reports are because headhunters are specialists dedicated to the collection of coded wire tags.

In summary, our results describing distribution and movements increase our understanding of Chinook salmon populations in Lake Michigan and provide valuable information on recreational fisheries. We believe that in Lake Michigan, Chinook salmon tend to be located high in the water column and in the southern portion of the lake during spring because of warmer water temperatures that coincidently have a higher concentration of prey. From May to July, fish near shore move north following the warming of surface water. During July and August, fish start to move away from the coast into deeper waters as nearshore and surface waters warm and prey distribution changes. The results suggest that minor changes in weather conditions can have an effect on the recreational fisheries by altering the distribution of Chinook salmon. Assuming Chinook salmon distributions respond to lake conditions, a rapid warming of a specific area of the lake is likely to precipitate a rapid decline in fishery catch rates as fish move offshore and become less densely aggregated in the water column.

The insights from this study have management implications relative to stocking locations and the fishing opportunities that they provide. Since Chinook salmon distribution seems to be determined by movements that can be affected by temperature and forage conditions, the number of fish released in a stocking area will mainly contribute to the seasonal fall fishery in the same area when fish return to spawn. Because the lake-wide fishery is not directly linked to site-specific stocking rates, but more probably to the movement patterns described herein, we recommend that managers consider survival of smolts associated with stocking sites as the most important criteria for stocking strategies. Also, if Chinook salmon distributions are determined by forage conditions and the abundance of alewives is declining (U.S. Geological Survey, Great Lakes Science Center, unpublished data), it is possible that a shift in the prey base will make salmon populations less available to the recreational fisheries. This possibility suggests that it is important for management to focus more effort in studying prey fish populations. Furthermore, our results of extensive Chinook salmon movements in Lake Michigan support management based on a singlestock hypothesis, although further work is needed to determine population structure of wild salmon and gene flow and also to refine our study of movements. Our results showing that fish moved between management units in Michigan and Wisconsin waters suggest that stocking and management regulations of the 
Chinook salmon recreational fishery must be coordinated among state agency jurisdictions. Finally, since our results indicate that fish undergo seasonal movements, probably influenced by environmental cues and prey movements, catch rates used as abundance indices that do not account for changes induced by environmental conditions over time could become biased.

\section{Acknowledgments}

Funding for this study was provided through a grant from the U.S. Environmental Protection Agency. Data used in this analysis were provided through the work of personnel at the Michigan Department of Natural Resources, Charlevoix Fisheries Research Station, with funding from Federal Aid in Sport Fish Restoration Study F-80-R and from the Game and Fish Protection Fund (Michigan Department of Natural Resources). In particular, we acknowledge the significant contributions of Paul Gelderblom, Pat O’Neill, Jerry Rakoczy, Tim Smigielski, Ron Svoboda, Sarah Thayer, and Donna Wesander, as well as the many seasonal employees (creel clerks, headhunters, and data-processing assistants), without whom the programs would not be possible.

\section{References}

Adlerstein, S. A., E. S. Rutherford, D. F. Clapp, J. A. Clevenger, and J. E. Johnson. 2007a. Estimating seasonal movements of Chinook salmon in Lake Huron from efficiency analysis of coded wire tag recoveries in recreational fisheries. North American Journal of Fisheries Management 27:792-803.

Adlerstein, S. A., E. S. Rutherford, J. A. Clevenger, J. E. Johnson, D. F. Clapp, and A. P. Woldt. 2007b. Lake trout movements in U.S. waters of Lake Huron interpreted from coded wire tag recoveries in recreational fisheries. Journal of Great Lakes Research 33:186-201.

Argyle, R. L. 1982. Alewives and rainbow smelt in Lake Huron: midwater and bottom aggregations and estimates of standing stocks. Transactions of the American Fisheries Society 111:267-285.

Aultman, D. C., and J. M. Haynes. 1993. Spring thermal fronts and salmonine sport catches in Lake Ontario. North American Journal of Fisheries Management 13:502-510.

Becker, R. A., J. M. Chambers, and A. R. Wilks. 1988. The new $S$ language: a programming environment for data analysis and graphics. Wadsworth and Brooks/Cole, Pacific Grove, California.

Bence, J. R., and K. D. Smith. 1999. An overview of recreational fisheries of the Great Lakes. Pages 259-306 in W. W. Taylor and C. P. Ferreri, editors. Great Lakes fisheries and policy management: a binational perspective. Michigan State University Press, East Lansing.

Benjamin, D. M., and J. R. Bence. 2003. Spatial and temporal changes in the Lake Michigan Chinook salmon fishery, 1985-1996. Michigan Department of Natural Resources,
Fisheries Research Report 2065, Ann Arbor. Available: www.michigandnr.com. (March 2008).

Brandt, S. B., D. M. Mason, E. V. Patrick, R. L. Argyle, L. Wells, P. A. Unger, and D. J. Stewart. 1991. Acoustic measures of the abundance and size of pelagic planktivores in Lake Michigan. Canadian Journal of Fisheries and Aquatic Sciences 48:894-908.

Brown, E. H. 1972. Population biology of alewives, Alosa pseudoharengus, in Lake Michigan, 1949-1970. Journal of the Fisheries Research Board of Canada 29:477-500.

Diana, J. S. 1990. Food habits of angler-caught salmonines in western Lake Huron. Journal of Great Lakes Research 16:271-278.

Dobiesz, N. E., D. A. McLeish, R. L. Eshenroder, J. R. Bence, L. C. Mohr, M. P. Ebener, T. F. Nalepa, A. P. Woldt, J. E. Johnson, R. L. Argyle, and J. C. Makarewicz. 2003. Ecology of the Lake Huron fish community, 1970-1999. Canadian Journal of Fisheries and Aquatic Sciences 62:1432-1451.

Elliott, R. F. 1993. Feeding habits of Chinook salmon in eastern Lake Michigan. Master's thesis. Michigan State University, East Lansing.

Haynes, J. M., and C. J. Keleher. 1986. Movements of Pacific salmon in Lake Ontario in spring and summer: evidence for wide dispersal. Journal of Freshwater Ecology 3:289297.

Haynes, J. M., D. C. Nettles, K. M. Parnell, M. P. Voiland, R. A. Olson, and J. D. Winter. 1986. Movements of rainbow steelhead trout (Salmo gairdneri) in Lake Ontario and a hypothesis for the influence of spring thermal structure. Journal of Great Lakes Research 12:304-313.

Henderson, B. A., and S. J. Nepszy. 1992. Comparison of catches in mono- and multifilament gill nets in Lake Erie. North American Journal of Fisheries Management 12:618-624.

Hilborn, R. 1990. Determination of fish movement patterns from tag recoveries using maximum likelihood estimators. Canadian Journal of Fisheries and Aquatic Sciences 47:635-643.

Hinke, J. T., G. M. Watters, G. W. Boehlert, and P. Zedonis. 2005. Ocean habitat use in autumn by Chinook salmon in coastal waters of Oregon and California. Marine Ecology Progress Series 285:181-192.

Holey, M. E., R. F. Elliott, S. V. Marcquenski, J. G. Hnath, and K. D. Smith. 1998. Chinook salmon epizootics in Lake Michigan: possible contributing factors and management implications. Journal of Aquatic Animal Health 10:202-210.

Höök, T. O., E. S. Rutherford, S. J. Brines, D. J. Schwab, and J. McCormick. 2004. Relationship between surface water temperature and steelhead distributions in Lake Michigan. North American Journal of Fisheries Management 24:211-221.

Johnson, J. E., R. M. Claramunt, D. Fielder, J. X. He, J. Schaeffer, D. Gonder, B. Breidert, D. F. Clapp, R. F. Elliott, C. P. Madenjian, P. Peeters, S. Robillard, D. M. Warner, and G. Wright. 2005. Analysis of the Chinook salmon populations of Lakes Huron and Michigan, 1985-2004. Report of the 2005 Great Lakes Fishery Commission upper lake meetings. Available: www. michigan.gov. (March 2008). 
Keller, M., K. D Smith, and R. W. Rybicki, editors. 1990. Review of salmon and trout management in Lake Michigan. Michigan Department of Natural Resources, Fisheries Special Report 14, Charlevoix.

Kitchell, J. F., and L. B. Crowder. 1986. Predator-prey interactions in Lake Michigan: model predictions and recent dynamics. Environmental Biology of Fishes 16:205-211.

Madenjian, C. P., G. K. Fahnenstiel, T. H. Nalepa, H. A. Vanderploeg, G. W. Fleischer, P. J. Schneeberger, D. M. Benjamin, E. B. Smith, J. R. Bence, E. S. Rutherford, D. S. Lavis, D. M. Robertson, D. J. Jude, and M. P. Ebener. 2002. Dynamics of the Lake Michigan food web, 1970-2000. Canadian Journal of Fisheries and Aquatic Sciences 59:736-753.

McCullagh, P., and J. A. Nelder. 1989. Generalized linear models. Chapman and Hall, London.

Myers, J. M., R. G. Kope, G. J. Bryant, D. Teel, L. J. Lierheimer, T. C. Wainwright, W. S. Grant, F. W. Waknitz, K. Neely, S. T. Lindley, and R. S. Waples. 2005. Status review of Chinook salmon from Washington, Idaho, Oregon, and California. NOAA Technical Memorandum NMFS-NWFSC-35.

Nelson, D. D., and J. G. Hnath. 1990. Lake Michigan Chinook salmon mortality, 1989. Michigan Department of Natural Resources, Technical Report 90-4, Ann Arbor.

Nettles, D. C., J. M. Haynes, R. A. Olson, and J. D. Winter. 1987. Seasonal movements of brown trout (Salmo trutta) in south-central Lake Ontario. Journal of Great Lakes Research 13:168-177.

Olson, R. A., J. D. Winter, D. C. Nettles, and J. M. Haynes. 1988. Resource partitioning in summer by salmonids in south-central Lake Ontario. Transactions of the American Fisheries Society 117:552-559.

Rutherford, E. S. 1997. Evaluation of natural reproduction, stocking rates, and fishing regulations for steelhead Oncorhychus mykiss, Chinook salmon O. tshawytscha, and coho salmon $O$. kisutch in Lake Michigan. Michigan Department of Natural Resources, Federal Aid in Sport
Fish Restoration, Project F-35-R-22, Final Report, Ann Arbor.

Rybicki, R., and D. F. Clapp. 1996. Diet of Chinook salmon in eastern Lake Michigan, 1991-1993. Michigan Department of Natural Resources, Research Report 2027, Lansing. Available: www.michigandnr.com. (March 2008).

Schmalz, P. J., M. J. Hansen, M. E. Holey, P. C. McKee, and M. Toneys. 2002. Lake trout movements in northwestern Lake Michigan. North American Journal of Fisheries Management 22:737-749.

Schneeberger, P., M. Toneys, R. Elliott, J. Jonas, D. Clapp, R. Hess, and D. Passino-Reader. 2001. Lakewide assessment plan for Lake Michigan fish communities. Great Lake Fisheries Commission, Special Report 1-64, Ann Arbor. Available: www.glfc.org. (March 2008).

Stewart, D. J., and M. Ibarra. 1991. Predation and production by salmonine fishes in Lake Michigan, 1978-1988. Canadian Journal of Fisheries and Aquatic Sciences 48:909-922.

Tody, W. H., and H. A. Tanner. 1966. Coho salmon for the Great Lakes. Michigan Department of Natural Resources, Fish Management Report 1, Lansing.

Walker, R. V., K. W. Myers, N. D. Davis, K. Y. Aydin, K. D. Friedland, H. R. Carlson, G. W. Boehlert, S. Urawa, Y. Ueno, and G. Amna. 2000. Diurnal variation in thermal environment experienced by salmonids in the North Pacific as indicated by data storage tags. Fisheries Oceanography 9:171-186.

Warner, D. M., R. M. Claramunt, and C. S. Faul. 2006. Status of pelagic prey fishes in Lake Michigan, 1992-2005. Annual Report to the Great Lakes Fishery Commission, Ann Arbor. Available: www.glsc.usgs.gov. (March 2008).

Wurster, C. M., W. P. Patterson, D. J. Stewart, J. N. Bowlby, and T. J. Stewart. 2005. Thermal histories, stress, and metabolic rates of Chinook salmon (Oncorhynchus tshawytscha) in Lake Ontario: evidence from intra-otolith stable isotope analyses. Canadian Journal of Fisheries and Aquatic Sciences 62:700-713. 